3. Books and journals are sent carriage paid from the Library, but members are responsible for the books from the time they leave the Library until they are received back.

4. Books damaged or lost while in possession of a member will be repaired at his expense or must be replaced by him.

5. A member borrowing a book or periodical from the Library shall be required to sign and return to the Librarian a form of receipt for the same, which will be regarded as an acceptance of these Regulations.

6. A member shall be entitled to retain a book or periodical borrowed from the Library for a period of twenty-eight days, unless the book is required by another member, in which case it can be recalled by the Librarian at the expiration of fourteen days.

7. In the event of a member failing to return any book or periodical within seven days after receiving notice from the Librarian (on the expiration of the period referred to in Rule 6), the Library Committee shall be at liberty to purchase another copy, the cost to be charged to such member, who shall not be allowed to borrow another book until the sum thus expended shall have been paid.

8. All communications should be addressed to "The Librarian, Royal MedicoPsychological Association, II, Chandos Street, Cavendish Square, W.I."

\title{
Circulation of Journals.
}

The following journals are available at the Library :

Acta Psychiatrica et Neurologica.

American Journal of Mental Deficiency.

American Journal of Orthopsychiatry.

American Journal of Psychiatry.

Annales Médico-Psychologiques.

Archives of Neurology and Psychiatry.

Brain.

British Journal of Addiction.

British Journal of Medical Psychology.

British Journal of Psychiatric Social Work.

Bulletin of World Federation of Mental Health

Digest of Neurology and Psychiatry.

Excerpta Medica, Neurology and Psychiatry.

Howard Journal.

International Journal of Psycho-A nalysis.

Journal of Abnormal and Social Psychology.

Journal of Nervous and Mental Disease.

Journal of Neurology, Neurosurgery and Psychiatry.

Journal of Psychology.

Mental Health.

Mental Hygiene.

Occupational Therapy (London).

Psychiatric Quarterly.

Psychological Abstracts.

\section{NOTICES BY THE REGISTRAR.}

The Diploma in Psychological Medicine.

The examination for the Association's Diploma in Psychological Medicine will be held annually in May and November. The examination comprises :

Part I (a) Psychology.

(b) Anatomy and Physiology in their relation to nervous and mental diseases.

Part II (a) Psychiatry.

(b) Psychosomatic Medicine and Neurology.

Fees are eight guineas for Part I and twelve guineas for Part II, and are payable to the Registrar, R.M.P.A.

Prospective candidates should apply to the Registrar at least two months before the examination at which they wish to sit.

Full particulars may be obtained from the Registrar, R.M.P.A., II, Chandos Street, London, W.I, on receipt of stamped, addressed envelope. 